\title{
RANCANG BANGUN ALAT PEMBUATAN NANOFIBER MENGGUNAKAN METODE ELECTROSPINNING
}

\author{
FATKHAH MUFLIKH MUBAROK ${ }^{1)}$, \& VALENTINUS GALIH VIDIA PUTRA ${ }^{2)}$ \\ ${ }^{1,2)}$ Jurusan Teknik Tekstil, Politeknik STTT Bandung \\ Jl. Jakarta No. 31 Bandung \\ Email: mubarok.blog@gmail.com ${ }^{l)}$,valentinus@kemenperin.go.id ${ }^{2)}$
}

\begin{abstract}
ABSTRAK
Electrospinning merupakan metode pembuatan nanofiber paling umum dan paling banyak digunakan. Prosesnya yang sederhana membuat elctrospinning banyak digunakan sebagai alat pembuatan nanofiber dengan berbagai material polimer. Pada penelitian ini telah dilakukan rancang bangun alat pembuatan nanofiber dengan metode electrospinning. Perancangan ini menggunakan modul step-up high voltage dengan output maksimal $50 \mathrm{kV}$. Pompa polimer menggunakan syrnge pump dengan diameter jarum sebesar $2 \mathrm{~mm}$. Jenis kolektor menggunakan bentuk silinder dengan diameter $7 \mathrm{~cm}$. Motor DC $12 \mathrm{v}$ dengan rangkaian potensiometer memungkinkan kolektor bergerak rotasi dan kecepatan rotasi yang dapat diatur. Jarak antar jarum dengan kolektor dapat diatur sebesar $5-15 \mathrm{~cm}$. Larutan PVA dengan konsentrasi $15 \%$ digunakan dalam pengujian. Hasil alat yang telah dirancang menghasilkan nanofiber berukuran jauh lebih kecil dari ukuran rambut manusia atau berkisar sebesar $84 \mu \mathrm{m}$.
\end{abstract}

Kata kunci: Electrospinning, Nanofiber, High Voltage.

\begin{abstract}
Electrospinning is the most common and most widely used method of making nanofiber. The simple process of elctrospinning is widely used as nanofibers manufacturing with various polymeric materials. In this study, a nanofiber manufacturing machine was made using the electrospinning method. The fabrication uses a step-up high voltage module with maximal output $50 \mathrm{kV}$. The polymer pump uses an syrnge pump with a needle diameter of $2 \mathrm{~mm}$. The type of collector is cylindrical tubes with diameter $7 \mathrm{~cm}$. DC motor with potentiometer circuit it possible collector rotating with controlability. The distance of the needle with a collector can be regulated with ranges $5-15 \mathrm{~cm}$. The PVA solution with $15 \%$ concentration makes for testing. The result of designed electrospinning machine can be producing nanofiber with size less than a human hair or around $84 \mu m$.
\end{abstract}

Keywords: electrospinning; nanofiber; high voltage

\section{PENDAHULUAN}

Nanoteknologi saat ini menjadi teknologi yang banyak dikembangkan dan diaplikasikan dalam kehidupan manusia. Secara konsep, nanoteknologi didefinisikan sebagai teknologi yang memungkinkan kendali struktural tigadimensi secara penuh atas bahan, proses dan alat pada skala atom. Artinya, teknologi ini memungkinkan orang untuk membuat suatu produk dengan sifat apapun yang diinginkan melalui pengaturan struktur bahan pada skala atom. Oleh sebab itu, nanoteknologi sering juga dipahami sebagai teknologi untuk proses manufaktur molekuler (Widodo, 2004). 
Menurut Subbiah, nanofiber dalam dunia tekstil merupakan serat yang memiliki diameter sebesar 100-500 nm. Nanofiber memiliki beberapa keuggulan seperti dimensi permukaan yang tinggi, modulus elastisitas tinggi, kekuatan tarik tinggi, serta mudah digabungkan dengan material lain seperti polimer, protein dan sel hidup. Nanofiber dapat diaplikasikan untuk berbagai bidang diantaranya medis, komposit, filtrasi, bioteknologi, dan kain pelindung (protective fabric). Salah satu aplikasi penggunaan nanofiber di bidang medis adalah penggunaanya sebagai pembalut luka. Produk membran nanofiber Kitosan-PVA yang dibuat dengan metode electrospinning sebagai bahan pembalut luka alternatif telah banyak digunakan di dunia medis. Selain itu, nanofiber juga digunakan sebagai penyusun pembuluh darah buatan, organ tubuh buatan, dan masker wajah medis dikarenakan nanofiber mampu mengantarkan obat langsung ke jaringan internal tubuh karena ukurannya yang lebih kecil dari sel darah (Krisnandika, 2017). Pembuatan nanofiber dapat dilakukan dengan beberapa metode diantaranya pemintalan serat multikomponen, pemintalan leleh dan electrospinning (Almetwally dkk., 2017).

Electrospinning secara umum terdiri dari tiga komponen yaitu sumber tegangan tinggi DC, syringe pump, dan collector plate atau collector drum. Pada prinsipnya mekanisme pembuatan nanofiber dengan electrospinning adalah dengan cara mendorong larutan polimer yang diberi listrik tegangan tinggi menggunakan syringe pump hingga membentuk butir larutan pada ujung nosel jarum. Butir larutan polimer yang telah terinduksi muatan listrik tersebut dibawah pengaruh medan listrik akan bergerak ke arah elektroda dengan muatan negatif dan disertai proses penguapan pelarut polimer, sehingga yang tertinggal pada plat pengumpul (collector plate) hanya serat polimernya saja (Li dkk., 2004).

Pengaturan electrospinning terdiri dari tiga komponen utama yaitu, catu daya tegangan tinggi, nosel jarum, dan kolektor (Gambar 1). Electrospinning dapat memproduksi serat dengan diameter dengan kisaran mikrometer hingga nanometer ketika gaya elektrostatis digunakan pada larutan statis (Park, 2010).

Sumber high voltage power suppply yang digunakan berupa listrik searah (direct current) dengan kontrol yang dapat diatur dan menghasilkan output maksimal sebesar 50
$\mathrm{kV}$. Larutan polimer dimasukan dalam reservoir dan dihubungkan ke sumber daya untuk menghasilkan jet polimer bermuatan. Larutan polimer diletakan pada suntikan dengan jarum suntik atau jarum logam dalam larutan polimer. Pompa pada suntikan digunakan untuk mendorong larutan polimer dan mengontrol laju aliran yang tepat. Plat yang digunakan untuk kolektor bersifat konduktif dan dialiri dengan arus negatif agar dapat mengasilkan nanofiber (Shi dkk., 2015).

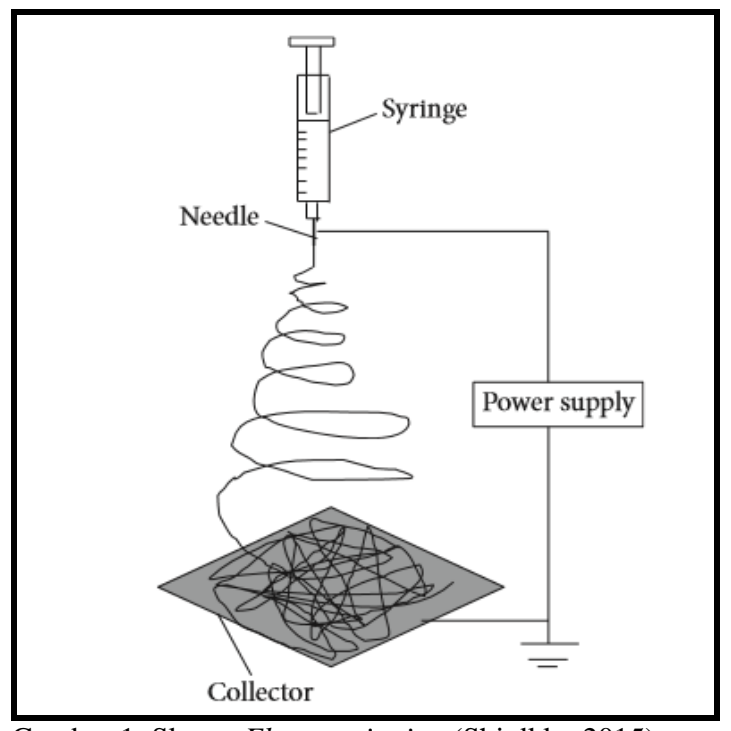

Gambar 1. Skema Electrospinning (Shi dkk., 2015)

Dilihat dari prinsip kerjanya, rancang bangun alat pembuatan nanofiber dengan metode electrospinning memungkinkan untuk dibuat dengan berbagai komponen dan material yang mudah ditemukan dalam kehidupan sehari-hari. Dalam perancangan tahap awal yang dilakukan adalah membuat desain rancangan dengan menyesuaikan spesifikasi yang akan dibuat. Perancangan alat dibuat sederhana dan dengan menggunakan komponen yang mudah ditemui dalam kehidupan sehari-hari. Setelah dilakukan perancangan, tahapan selanjutnya adalah mempersiapkan material dan bahan yang akan digunakan sebagai komponen pada electrospinning. Tahapan terakhir adalah mempersiapkan perlengkapan sarana yang akan digunakan untuk melaksanakan rancang bangun alat pembuatan nanofiber dengan metode electrospinning.

\section{TINJAUAN PUSTAKA \\ 1. Nanofiber}

Nanoteknologi didefinisikan sebagai material, perangkat, dan sistem dengan dimensi 
nanometer. Inti dari nanoteknologi adalah ukuran dan kontrol (Ramsden, 2015). Material yang direduksi menjadi skala nano dapat menunjukan sifat yang berbeda dengan yang berskala makro, hal ini akan memungkinkan material tersebut memiliki sifat yang unik. Dasarnya adalah sifat-sifat dapat berubah ketika ukuran suatu zat diperkecil hingga kisaran nanometer (Gouda dan Patra, 2013).

Penerapan nanoteknologi dalam industri tekstil dikenal dengan nanofiber yang memungkinkan untuk meningkatkan daya tahan kain, meningkatkan kenyamanan, sifat higienis, dan juga mengurangi biaya produksinya. Nanoteknologi juga menawarkan banyak keuntungan dibandingkan dengan proses konvensional dalam hal ekonomi, hemat energi, ramah lingkungan, dan penyimpanan bahan pada skala mikroskopis (David, 2002).

Nanofiber diangkat dalam beberapa penelitian yang bertujuan menghasilkan kain dengan kinerja fungsional yang berbeda. Nanopartikel dapat memberikan daya tahan tinggi untuk kain dan menyebabkan peningkatan daya kain yang diinginkan. Ukuran partikel juga menjadi peran utama dalam menentukan sifat kerekatan pada serat (Gouda dan Patra, 2013). Berbagai macam aplikasi nanoteknologi tekstil sudah ada di pasaran saat ini. Beberapa aplikasi nanofiber diantaranya pada industri tekstil di bidang olahraga, medis, serta teknologi bahan pakaian untuk perlindungan di lingkungan yang ekstrim. Penggunaan nanofiber memungkinkan produk tekstil menjadi multifungsi dan menghasilkan kain dengan fungsi khusus, termasuk antibakteri, perlindungan UV, anti air dan noda serta anti-bau (Kathiervelu, 2003).

\section{Metode Electrospinning}

Electrospinning merupakan salah satu metode pembentukan nanoiber melalui pancaran muatan listrik dari suatu larutan atau cairan polimer. Teknik ini telah dipatenkan oleh Formhals pada tahun 1934 (Marno dkk, 2018). Electrospinning adalah proses sederhana dan komprehensif untuk menghasilkan nanofiber dari bahan yang seperti polimer, komposit dan keramik. Komponen electrospinning terdiri dari tiga bagian utama yaitu, pembangkit daya tegangan tinggi, jarum suntik logam, dan kolektor konduktif (AlHazeem, 2018).

\section{a) Prinsip Electrospinning}

Electrospinning menghasilkan serat dengan diameter dari skala nanometer hingga mikrometer. Konfigurasi pemasangan komponen electrospinning secara umum terdiri dari tiga komponen utama seperti yang ditunjukkan pada Gambar 1. Daya bertegangan tinggi (dalam tegangan $\mathrm{kV}$ ), syrnge pump dengan jarum nosel, dan kolektor (collector plate).

Susunan pemasangan listrik tegangan tinggi diikatkan pada larutan polimer melalui jarum logam dan papan kolektor sebagai ground (-). Larutan polimer dimasukan dalam pump dan diberi tekanan yang sesuai, larutan akan keluar melewati ujung jarum dan membentuk butiran-butiran. Gaya elektro-statik akan timbul dikarenakan jarum logam yang dialiri listrik. Interaksi antara medan listrik dan medan fluida membentang arus fluida dan membuatnya mengalami gerakan mencambuk. Hal ini menyebabkan aliran jet terus menerus memanjang sebagai filamen yang panjang. Hasil dari serat electrospun yang dihasilkan terdapat pada papan kolektor (Shi, 2015)

\section{b) Mekanisme Electrospinning}

Electrospinning merupakan proses pembuatan serat dengan metode pancaran dari suatu larutan atau cairan polimer yang dialiri muatan listrik. Larutan polimer dimasukan ke dalam tabung syrnge pump yang telah terpasang jarum nosel. Kemudian syrnge pump ditekan sehingga larutan polimer tertekan dengan laju alir secara konstan. Selanjutnya tegangan tinggi pada tingkat $5-50 \mathrm{kV}$ diaplikasikan pada jarum. Salah satu bagian penting dalam electrospinning adalah pemberian tegangan tinggi kepada larutan. Secara umum tegangan diatas $6 \mathrm{kV}$ baik positif atau negatif dapat menyebabkan larutan untuk bergerak menuju ujung jarum dan membentuk taylor cone selama proses awal pembentukan jet (Al-Hazeem, 2018). Mekanisme dari proses electrospinning dapat dilihat pada Gambar 2. 


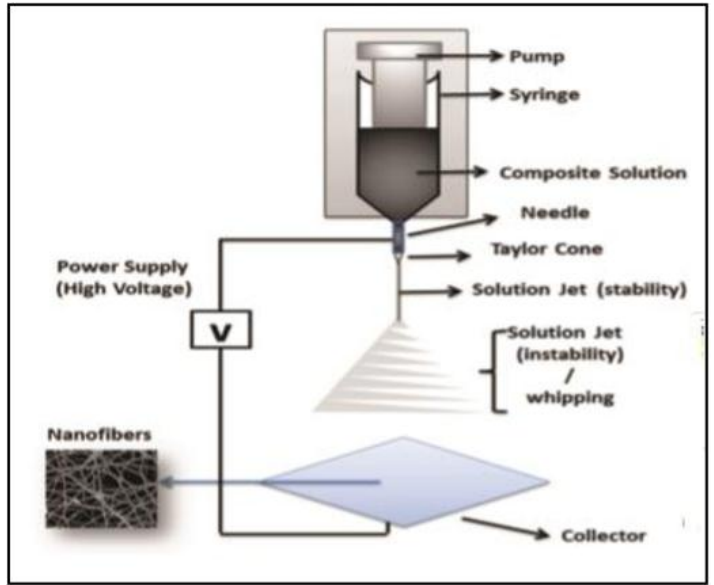

Gambar 2. Mekanisme Electrospinning (Al-Hazeem, 2018)

Pancaran fluida dari larutan polimer bergerak ke papan kolektor yang juga dialiri dengan tegangan listrik negatif (-) atau ground. Menurut Marno dkk. (2018), ketika bergerak ke kolektor, pelarut menguap lalu serat mulai menipis dan menjalar sebagai akibat dari ketidakstabilan lekukan elektrostatik. Serat yang dikumpulkan biasanya sangat sedikit, ukurannya dapat bervariasi tergantung pada kondisi electrospinning yang digunakan. Beberapa parameter larutan yang mempengaruhi dalam pembentukan serat di papan kolektor pada proses electrospinning adalah tegangan permukaan, viskositas (kekentalan), konduktivitas, dan konstanta dielektrik larutan.

\section{Komponen Electrospinning}

Komponen utama electrospinning terdiri dari sumber tegangan tinggi DC (High Voltage Power Supply DC), Syringe Pump dan Collector (Marno, 2018).

\section{a) High Voltage Power Supply DC}

Metode electrospinning dibutuhkan pembangkit listrik yang memiliki tegangan tinggi. Menurut Flower dkk., para peneliti menggunakan tegangan dengan kisaran $20-50 \mathrm{kV}$ saat membuat serat electrospun dalam skala nano. Power Supply merupakan komponen yang mempunyai fungsi sebagai pemberi suatu tegangan serta arus listrik. Pada dasarnya Power Supply memerlukan sumber energi listrik yang kemudian diubahnya menjadi energi listrik yang dibutuhkan oleh perangkat elektronika lainya (Kho, 2014). Power Supply $D C$ umumnya memiliki empat bagian utama agar dapat menghasilkan arus DC yang stabil. Bagian tersebut diantaranya adalah Transfor- mator, Rectifier, Filter, dan Voltage Regulator.

Tesla coil adalah sebuah media pembangkit tegangan tinggi dengan frekuensi tinggi, sehingga dengan arus yang kecil mampu menghasilkan tegangan yang besar (Zulianto, 2017). Prinsip kerja tesla coil sama dengan transformator step-up yang dapat menghasilkan tegangan output lebih besar. Transformator step-up adalah transformator yang memiliki lilitan sekunder lebih banyak daripada lilitan primer, sehingga berfungsi sebagai penaik tegangan.

Transformator ini biasa ditemui pada pembangkit tenaga listrik sebagai penaik tegangan yang dihasilkan generator menjadi tegangan tinggi yang digunakan dalam transmisi jarak jauh (Putra, 2015). Umumnya konstruksi transformator daya secara singkat terdiri dari inti yang terbuat dari lembaran lembaran plat besi lunak atau baja silikon yang diklem menjadi satu, kemudian tembaga dibelitkan pada inti secara konsentris atau spiral.

\section{b) Syrnge pump}

Syrnge pump atau pompa semprot merupakan bagian dari alat electrospinning yang berfungsi untuk menekan larutan polimer agar dapat keluar melewati jarum nosel. Syrnge pump juga berfungsi untuk mengatur laju semprot dari larutan polimer yang digunakan. Syrnge pump berbentuk tabung dengan volume tertentu yang berguna untuk menampung larutan polimer yang akan disemprotkan. Kecepatan dan volume penyemprotan larutan polimer diatur oleh syrnge pump dengan penekanan. Ketika dilakukan penekanan, larutan yang ada didalam akan terdorong dan keluar melalui jarum nosel.

Jarum nosel merupakan jarum logam yang bersifat konduktor dan bertujuan untuk dialiri listrik tegangan tinggi agar larutan polimer yang keluar membentuk pancaran. Menurut Marno dkk (2018), Ketika tegangan tinggi pada tingkat $5-30 \mathrm{kV}$ diaplikasikan pada jarum, larutan polimer berkembang membentuk kerucut, yang disebut dengan Taylor Cone (Gambar 3). Pancaran fluida dikeluarkan dan dipercepat menuju kolektor dasar. 


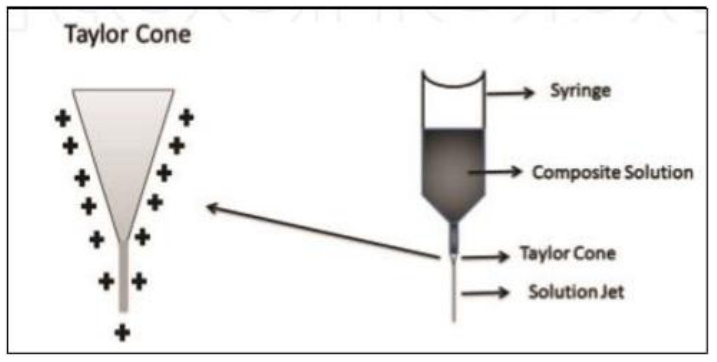

Gambar 3. Pembentukan Taylor Cone (Al-Hazeem, 2018).

\section{c) Collector}

Collector plate berfungsi sebagai kolektor serat electrospun yang telah terbentuk dari proses electrospinning. Kolektor terbuat dari material yang bersifat konduktor dan dialiri listrik dengan arus negatif (-) atau ground. Menurut Dalton (2011), ada dua jenis kolektor yaitu lempengan datar dan silinder radial yang dapat digerakan berputar. Jenis kolektor dapat dilihat pada Gambar 4.

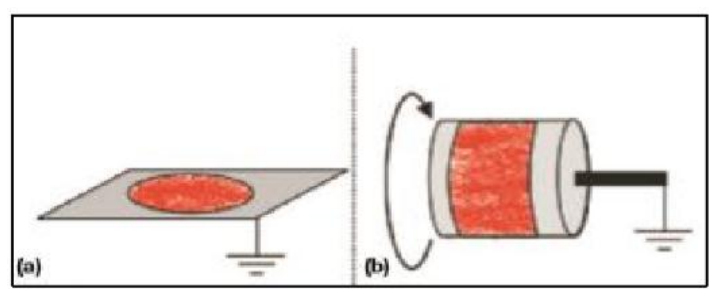

Gambar 4. Papan Kolektor Datar (a), Papan Kolektor Radial (b) (Dalton, 2011).

\section{Polimer PVA (Polyvinyl Alcohol)}

Polimer adalah material yang paling umum digunakan untuk electrospinning. Beberapa polimer meliputi polimer industri, polimer biodegradable, polimer khusus dan polimer alami. Secara umum, polimer ini harus memiliki berat molekul tinggi dan dapat dilarutkan dalam pelarut. Untuk polimer yang penting secara komersial seperti polietilena dan polipropilena yang larut dalam beberapa pelarut, memungkinkan dilakukan dengan proses electrospinning (Teo, 2017).

Polyvinyl Alcohol (PVA) adalah polimer polihidroksi yang larut dalam air dan dapat terbiodegradasi yang telah dipelajari secara intensif karena stabilitas thermal yang baik, bio-kompatibilitas, ketahanan kimia, dan tidak mahal. PVA dihasilkan dari polimerisasi vynil acetate menjadi polyinyl acetate, kemudian diikuti dengan hidrolisis polyvinyl acetate menjadi PVA (Gambar 5). PVA bersifat tidak beracun dan dapat larut dalam air sehingga banyak dimanfaatkan dalam berbagai bidang, di antaranya bidang medis dan farmasi (Ropikoh, 2019).

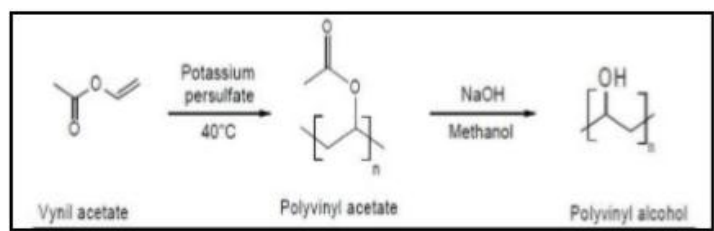

Gambar 5. Polimerisasi Vynil Acetate menajdi Polyvinyl Alcohol (Ropikoh, 2019)

Menurut Hong dkk (2007) serat PVA nanokomposit yang diperkuat dengan nanopartikel Ag dapat digunakan sebagai pembalut luka. Pembuatan nanofiber komposit berbasis PVA menggunakan metode electrospinning telah banyak dilakukan. Beberapa refrensi menjelaskan bahwa penambahan material anorganik dengan PVA akan mempengaruhi sifat dari serat yang berukuran nano.

\section{METODE PENELITIAN}

Pada penelitian ini, telah dilakukan perancangan dan pembuatan alat pembuatan nanofiber dengan metode electrospinning. Tahapan penelitian ini meliputi tahap persiapan alat dan bahan, perancangan dan perakitan, dan pengujian alat.

\section{Skema Percobaan}

Skema percobaan pada penelitian ini dapat dilihat pada Gambar 6 berikut.

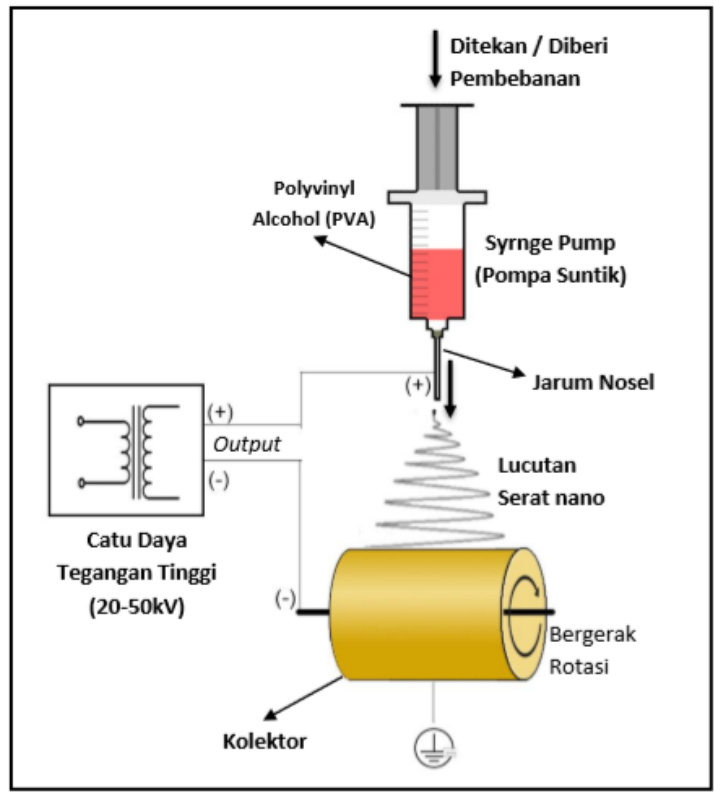

Gambar 6. Skema Percobaan Alat Electrospinning

Rancang bangun alat electrospinning menggunakan catu daya tegangan tinggi (High Voltage Power Supply) sebagai daya untuk membentuk lucutan dari larutan Polyvinyl Alcohol (PVA) yang diletakan pada 
Syrnge pump (pompa suntikan) dan keluar melalui nosel jarum menjadi serat dalam ukuran nano. Papan kolektor terbuat dari material yang bersifat konduktor agar dapat dialiri listrik, disini menggunakan kaleng berbentuk silinder dan dilapisi dengan alumunium foil yang berfungsi untuk kolektor nanofiber yang dihasilkan. Dinamo Motor DC 8-35 $\mathrm{V}$ berfungsi untuk menggerakan papan kolektor agar bergerap berputar, kecepatan dari Dinamo Motor DC 8-35 V diatur dengan modul PWM Motor Speed Control Potensio DC 3-35 V.

\section{Persiapan Alat dan Bahan}

Tahapan persiapan berupa persiapan peralatan dan bahan yang dibutuhkan dalam pembuaatan rancang bangun alat pembuatan nanofiber. Peralatan yang digunakan ditunjukan pada Tabel 1. sebagai berikut :

Tabel 1. Alat yang digunakan

\begin{tabular}{|c|c|c|}
\hline No & Nama & Fungsi \\
\hline 1 & $\begin{array}{l}\text { Multitester } \\
\text { Analog }\end{array}$ & $\begin{array}{l}\text { Digunakan untuk mengukur te- } \\
\text { gangan dan arus. }\end{array}$ \\
\hline 2 & Mesin Bor & $\begin{array}{l}\text { Digunakan untuk melubangi } \\
\text { setiap bagian komponen agar } \\
\text { dapat dipasangkan. }\end{array}$ \\
\hline 3 & $\begin{array}{l}\text { Gergaji } \\
\text { Besi }\end{array}$ & $\begin{array}{l}\text { Digunakan untuk memotong } \\
\text { besi dan kaca akrilik. }\end{array}$ \\
\hline 4 & Solder & $\begin{array}{l}\text { Digunakan untuk memasangkan } \\
\text { atau membongkar kabel. }\end{array}$ \\
\hline 5 & Glue Gun & $\begin{array}{l}\text { Digunakan untuk melelehkan } \\
\text { lem stick untuk merekatkan } \\
\text { komponen. }\end{array}$ \\
\hline 6 & $\begin{array}{l}\text { Peralatan } \\
\text { Kerja } \\
\text { lainya }\end{array}$ & $\begin{array}{l}\text { Digunakan sebagai alat pendu- } \\
\text { kung dalam penelitian ini, per- } \\
\text { alatan kerja lainya meliputi } \\
\text { obeng, tang, kunci pas, timah, } \\
\text { isolasi, dan lain-lain. }\end{array}$ \\
\hline
\end{tabular}

Bahan yang digunakan dalam pembuatal alat electrospinning dapat dilihat pada Tabel 2 sebagai berikut.

Tabel 2. Bahan yang digunakan

\begin{tabular}{|c|c|c|}
\hline No & Nama & Fungsi \\
\hline 1 & $\begin{array}{l}\text { Power } \\
\text { Supply } \\
\text { Adaptor DC } \\
3-24 \text { V } 2 A\end{array}$ & $\begin{array}{l}\text { Digunakan sebagai sumber } \\
\text { tegangan DC dengan meng- } \\
\text { ubah tegangan AC dari sum- } \\
\text { ber listrik. Dibeli di Jaya } \\
\text { Plaza, Bandung. }\end{array}$ \\
\hline 2 & $\begin{array}{l}\text { Modul } \\
\text { Generator } \\
\text { Step-Up } \\
\text { High } \\
\text { Voltage } 50 \\
k V\end{array}$ & $\begin{array}{l}\text { Digunakan untuk menaikan } \\
\text { tegangan (step-up) dari DC 3- } \\
6 \mathrm{v} \text { menjadi } 50 \mathrm{kV} \text {. Dibeli di } \\
\text { Survy2014 Store, China. }\end{array}$ \\
\hline
\end{tabular}

3 Dinamo Digunakan untuk memutarMotor DC 8- kan kaleng silinder kolektor $35 \mathrm{~V} \quad$ serat yang dibuat. Dibeli di Jaya Plaza, Bandung.

4 Modul PWM Digunakan untuk pengatur Motor Speed kecepatan putaran motor DC Control yang memutarkan silinder. Potensio DC Dibeli di Jaya Plaza, Ban3-35V

5 Saklar DC dung.

bungkan dan memutuskan arus utama.

6 Kaleng Digunakan sebagai papan Silinder kolektor (collector plate) unDiameter 7 tuk nanofiber yang dibuat

$\mathrm{cm}$

7 Poros

Stainless

Steel 3x400

$\mathrm{mm}$

$8 \quad$ Mini

Bearing 3

$\mathrm{mm}$

9 Belt dan

Pulley

Digunakan untuk poros berputar kaleng silinder kolektor serat.

Digunakan untuk mejaga poros kaleng silinder agar dapat berputar dengan stabil.

Digunakan sebagai elemen penghubung yang menghubungkan dinamo motor dengan kaleng silinder.

10 Akrilik Digunakan untuk kerangka Transparan 4 penutup (casing).

$\mathrm{mm}$

11 Plat Besi 3 Digunakan untuk kerangka $\mathrm{mm} \quad$ utama yang berfungsi untuk menopang komponen-komponen utama dan juga digunakan sebagai alas.

12 Plat Besi 2 Digunakan untuk dudukan $\mathrm{mm} \quad$ komponen syrnge pump (pompa suntikan)

13 Poros Ulir 8 Digunakan untuk menaik-tu$\mathrm{mm} \quad$ runkan pompa suntikan dan juga mengatur jarak lucutan antara ujung jarum dengan papan kolektor

14 Syrnge pump Digunakan sebagai tempat $20 \mathrm{~mL}$ polimer dan memompa la(Pompa rutan polimer.

Suntikan)

15 Jarum Suntik Digunakan untuk melucutkan Tumpul 2 polimer dan dialiri tegangan $\mathrm{mm}$

16 Alumunium Digunakan untuk melapisi Foil

17 Serbuk Polyvinyl Alcohol (PVA)

18 Capit Buaya Digunakan untuk menjepit $45 \mathrm{~mm}$

\section{permukaan kaleng silinder.}

Digunakan sebagai bahan baku pembuatan serat. Dibeli di Gudang Kimia, Yogyakarta.

Digunakan untuk menjepit
jarum suntik agar teraliri listrik. 
19 Kabel

Digunakan untuk menghubungkan komponen-komponen listrik.

20 Mur, Baut, Digunakan untuk memasangdan Sekrup kan seluruh komponen.

\section{Perancangan dan Pembuatan}

a) Kerangka dan Penutup (casing)

Bagian kerangka mengunakan bahan besi plat dan bagian penutup (casing) menggunakan bahan kaca akrilik.
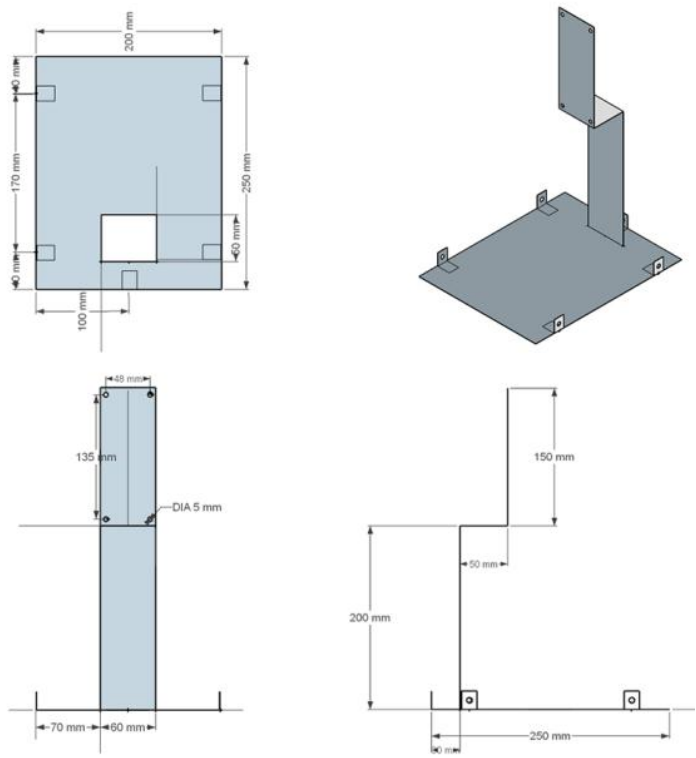

Gambar 7. Desain Isometrik Kerangka Utama
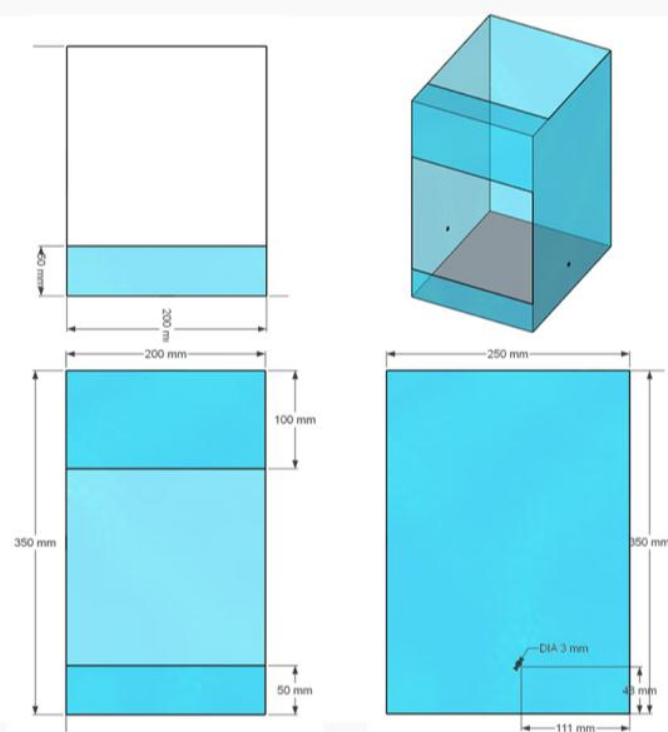

Gambar 8. Desain Isometrik Penutup (Casing)

\section{b) Syrnge pump}

Bagian ini menggunakan pompa suntik yang diletakan dengan dudukan yang terbuat dari bahan besi plat tebal $2 \mathrm{~mm}$ yang digabungkan dengan mur panjang (long nut) dan diletakan pada poros ulir. Bagian syrnge pump ini dapat bergerak naik turun dengan bantuan mur panjang dan poros ulir yang diputar. Poros ulir ujungnya dimasukan pada bearing agar bisa diputarkan dengan lancar dan pada bearing diberi bantalan (pillow block) agar bagian ini dapat diletakan pada kerangka.

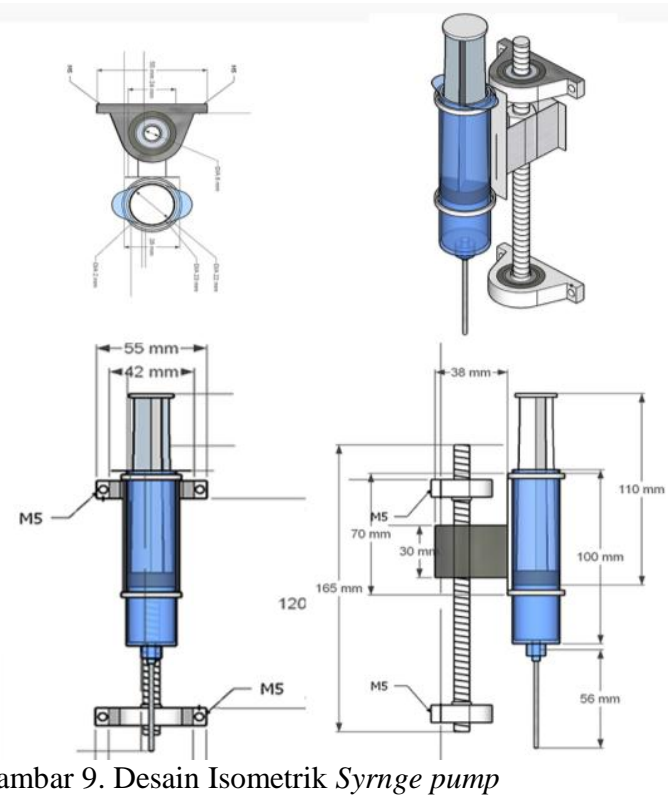

c) Collector

Bagian kolektor terdiri dari kaleng silinder berukuran diameter $70 \mathrm{~mm}$ dan panjang $80 \mathrm{~mm}$. Kaleng dipasangkan pada poros dengan ukuran diameter $3 \mathrm{~mm}$ dan panjang $200 \mathrm{~mm}$ dan didukan pada penutup alat. Kolektor tersebut akan berputar dengan bantuan Motor DC yang dihubungkan dengan elemen transmisi berupa belt dan pulley. Perancangan desain bagian kolektor dapat dilihat pada Gambar 10.
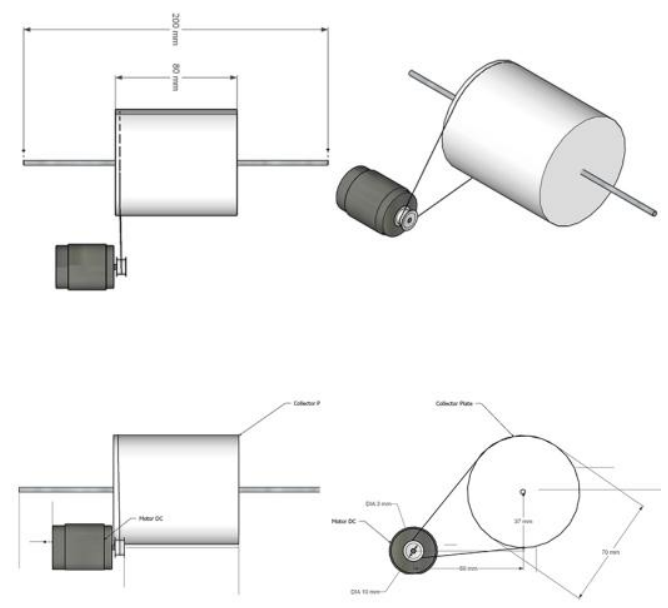

Gambar 10. Desain Isometrik Collector 


\section{d. High Voltage Power Supply DC}

High Voltage Power Supply terdiri dari power supply adaptor, saklar, dan Modul Generator StepUp High Voltage. Power supply adaptor dapat di setel (adjustable) dengan rentang $3-24 \mathrm{v}$ dan kuat arus sebesar $2 \mathrm{~A}$, kemudian output dari power supply adaptor dihubungkan dengan modul Generator StepUp High Voltage yang dapat menghasilkan tegangan hingga $50.000 \mathrm{~V}$ atau $50 \mathrm{kV}$. Output dari Generator StepUp High Voltage dengan arus positif dihubungkan ke nosel jarum pada syrnge pump dan arus negatif dihubungkan ke bagian kolektor. Diagram High Voltage Power Supply dilihat pada Gambar 11 berikut.

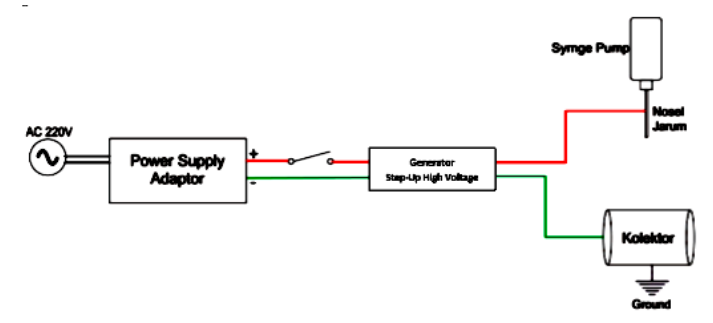

Gambar 11. Diagram High Voltage Power Supply DC

e). Motor DC

Bagian komponen kolektor terdiri dari power supply adaptor, Modul PWM Motor Speed Control Potensiometer 3-35 V, dan Motor DC 8-24 V. Power supply adaptor dihubungkan dengan Modul PWM Motor Speed Control Potensiometer 3-35 V, kemudian dihubungkan ke Motor DC 8-24 V.

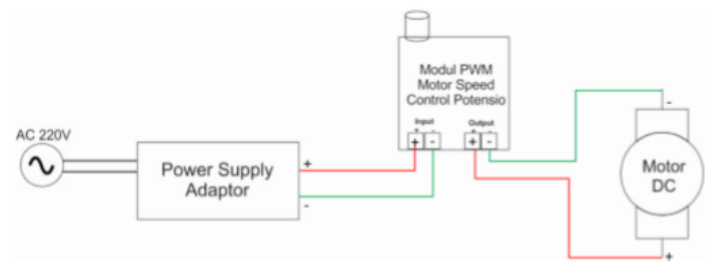

Gambar 12. Diagram Motor DC

\section{Pengujian}

Pengujian diawali dengan pembuatan polimer menggunakan serbuk Polyvinyl Alcohol (PVA). Serbuk PVA diambil dan ditimbang dengan timbangan digital hingga berat 15 gram untuk pembuatan PVA 15\%. PVA dimasukan pada gelas piala kemudian dimasukan aquades sebesar $100 \mathrm{~mL}$ yang telah diukur dengan gelas ukur. Gelas piala yang telah berisi serbuk PVA dan aquades ditempatkan pada magnetic stirrer hot plate. Magnetic stirrer dinyalakan, disetel dengan kecepatan $300 \mathrm{rpm}$ dan suhu $80^{\circ} \mathrm{C}$ selama 2 jam.
Alat pembuatan nanofiber disiapkan dengan kabel input power supply dihubungkan pada aliran listrik PLN. Kolektor dilapisi dengan alumunium foil. Larutan PVA $15 \%$ dimasukan pada tabung syrnge pump sebanyak $10 \mathrm{~mL}$. Kabel capit buaya berwarna merah dihubungkan pada nosel jarum dan yang berwarna hitam dihubungkan pada kolektor. Jarak jarum nosel dengan kolektor disetel dengan jarak $10 \mathrm{~cm}$. Tegangan disetel sebesar $40 \mathrm{kV}$ dengan mengatur potensiometer yang terletak pada power supply. Alat dinyalakan dengan menekan saklar power pada bagian belakang alat.

\section{HASIL DAN PEMBAHASAN \\ 1. Pembuatan Alat}

Setelah dilakukan desain perancangan dan perakitan alat pembuatan nanofiber dengan metode electrospinning maka didapat hasil pembuatan sebagai berikut :

Alat yang dibuat menggunakan bahan baku dan komponen yang mudah ditemukan dan dengan harga terjangkau. Walaupun demikian, alat yang dibuat tetap sesuai prinsip dasar dari mekanisme electrospinning itu sendiri yaitu High Voltage Power Supply DC mengeluarkan arus dengan skala $\mathrm{kV}$ (kilo volt) kemudian arus positif dihububungkan pada nosel jarum dan arus negatif dihubungkan pada kolektor. Polimer larutan Polyvinyl Alcohol yang berada pada syrnge pump didorong dengan tekanan tertentu kemudian akan timbul lucutan akibat pengaruh elektrostatis yang terjadi. Hasil pembuatan alat dapat dilihat pada Gambar 13 dan Gambar 14.

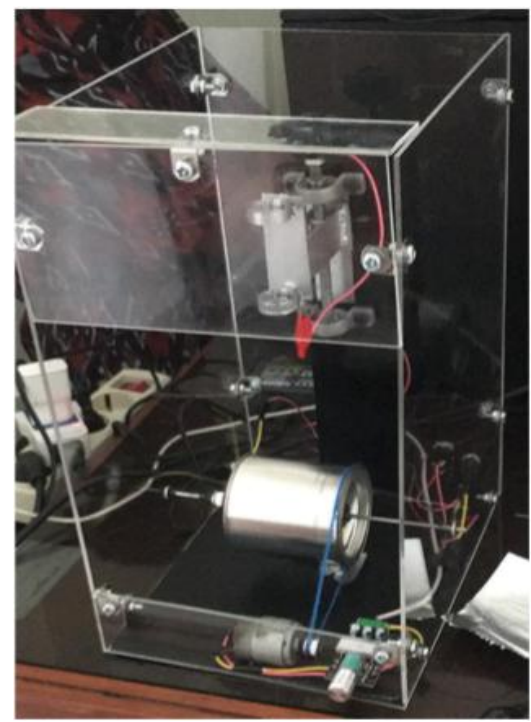

Gambar 13. Hasil Pembuatan Alat 

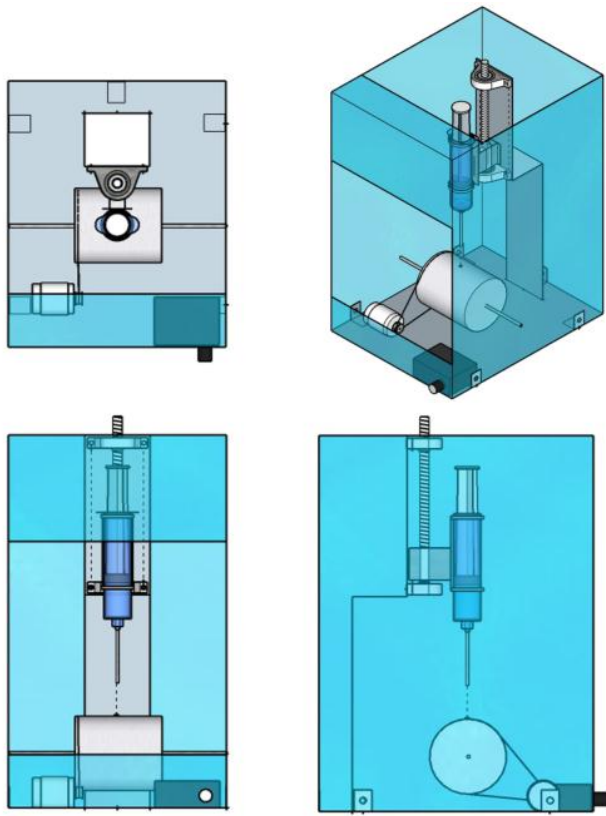

Gambar 14. Desain Isometrik Hasil Pembuatan Alat

Komponen dan material yang digunakan dalam pembuatan alat menggunakan material yang mudah didapatkan. Pemilihan material sebagai komponen pembuat alat menggunakan material yang terjangkau namun tetap dapat digunakan dengan baik. Selain itu, diperhatikan juga jenis dan kualitas dari material yang dipilih agar alat dapat berjalan dengan baik. Proses pembuatan alat sebagian besar dilakukan sesuai perancangan yang telah dilakukan.

\section{Hasil Pembuatan Nanofiber PVA}

Pengujian alat untuk pembuatan nanofiber menggunakan larutan PVA 15\% dengan parameter tegangan tinggi $40 \mathrm{kV}$ dan jarak jarum menuju kolektor sebesar $10 \mathrm{~cm}$. Nanofiber terkumpul pada kolektor yang telah dilapisi dengan alumunium foil. Hasil pembuatan nanofiber dapat dilihat pada Gambar 15 sebagai berikut:

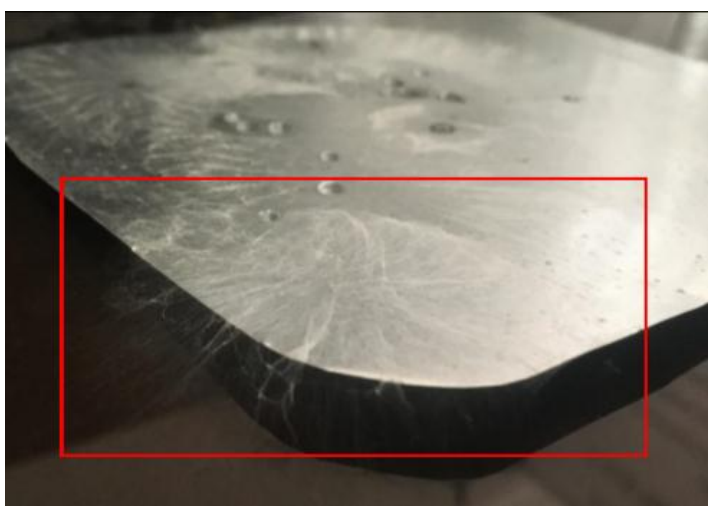

Gambar 15. Hasil Pembuatan Nanofiber PVA.
Gambar 15 menunjukan bahwa dari alat pembuatan nanofiber yang telah dirancang dan dibuat dapat menghasilkan nanofiber yang terbentuk seperti membran berwarna putih halus. Nanofiber yang tampak pada Gambar 15 terlihat belum homogen dan terdapat banyak tetesan dari larutan PVA yang menetes dan tidak terlucut secara elektrostatis. Untuk memastikan nanofiber yang terbentuk, maka dilakukan pengujian mikroskop digital. Untuk menentukan ukuran dari nanofiber yang terbentuk, dikomparasikan dengan rambut manusia yang disejajarkan dengan serat pada mikroskop digital. Hasil uji mikroskop dapat dilihat pada Gambar 16 sebagai berikut.

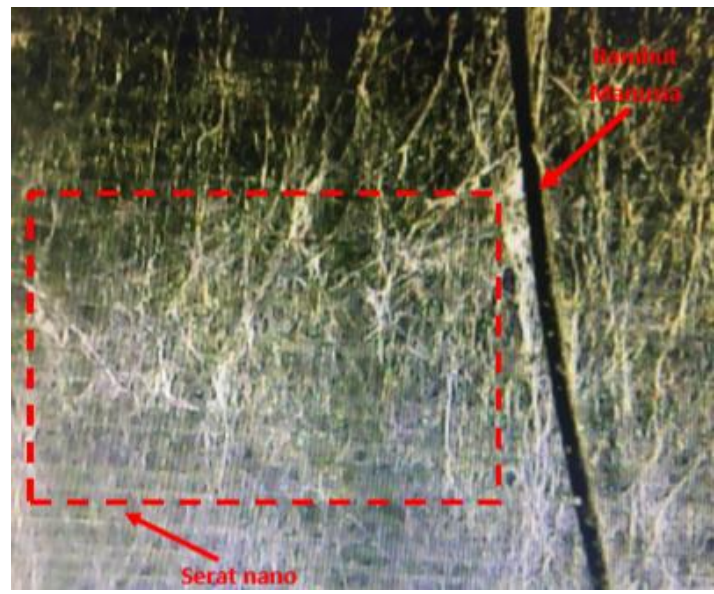

Gambar 14. Hasil Pengujian Nanofiber dengan Mikroskop Digital.

Mikroskop yang digunakan merupakan mikroskop digital dengan merk DinoLite. Hasil dari Gambar 3.10 merupakan hasil mikroskop digital dengan perbesaran sebesar 200x. Gambar 3.10 di atas menunjukan bahwa ukuran dari nanofiber yang terbentuk lebih kecil dari rambut manusia. Menurut Loussouarn dkk., (2016) ukuran diameter rambut manusia di asia memiliki rata-rata sebesar $84 \mu \mathrm{m}$. Berdasarkan hasil uji mikroskop yang terlihat, ukuran penampang nanofiber yang terbentuk sudah jauh lebih kecil dari ukuran rambut.

\section{KESIMPULAN}

Berdasarkan hasil penelitian tentang rancang bangul alat pembuatan nanofiber dengan metode electrospinning, maka dapat diperoleh kesimpulan sebagai berikut.

1. Pembuatan alat ini menggunakan metode electrospinning dengan bagian utama 
berupa kerangka, High Voltage Power Supply DC, syrnge pump dan collector.

2. Metode electrospinning merupakan metode paling sederhana dalam pembuatan nanofiber. Bahan yang digunakan dalam pembuatan rancang bangun alat ini menggunakan bahan yang mudah didapatkan dalam kehidupan sehari-hari sehingga alat pembuatan nanofiber yang dirancang memiliki kelebihan secara ekonomis (murah).

3. Hasil pengujian alat pembuatan nanofiber, menghasilkan nanofiber PVA dengan ukuran kurang dari $84 \mu \mathrm{m}$. Hal ini menunjukan bahwa nanofiber yang dihasilkan sudah atau mendekati ukuran nanometer

\section{DAFTAR PUSTAKA}

[1] Al-Hazeem, N. Z. (2018). Nanofibers and Electrospinning Method. Intech Open.

[2] Almetwally, A. A., El-Sakhawy, M., Elshakankery, M. H., \& M., H. K. (2017). Technology of nano-fibers: Production techniques and properties. Journal of the Textile Association.

[3] Dalton, P. L. (2011). Electrospun Fibers for Drug Delivery. Comprehensive Biomaterials, Vol 4.

[4] David, S. (2002). Nanoparticle-based Permanent Treatments for Textiles. United State Patent, , No 6,607: 994.

[5] Kathiervelu, S. (2003). Applications of nanotechnology in fiber finishing. Synth. Fibres.

[6] Krisnandika, V. E. (2017). Produksi Nanofiber dan Aplikasinya dalam Pengolahan Air. Institut Teknologi Bandung.

[7] Li, D., \& Xia, Y. (2004). Electrospinning of Nanofibers: Reinventing the Wheel? Advance Materials.

[8] Loussourant, G., Lozano, I., Panhard, S., Collaudin, C., El Rawadi, C., \& Genain, G. (2016). Diversity in human hair growth, diameter, colour and shape. An in vivo study on young adults from 24 different ethnic groups observed in the five continent. L'OREAL Research and Innovation.

[9] Marno, Widianto, E., Sunarjo, J., \& Santosa, A. (2018). Perancangan dan Pengembangan Sistem Electrospinning sebagai Teknologi dalam Pembuatan Nanofiber. INVOTEK, Jurnal Inovasi Vokasional dan Teknologi.

[10] Park, J.-S. (2010). Electrospinning and its applications. Advances in Natural Sciences

[11] Patra, J. K., \& Goudra, S. (2013). Application of nanotechnology in textile engineering: An overview. Journal of Engineering and Technology Research.

[12] Putra, R. A. (2015). Analisa Beban Tidak Seimbang Pada Transformator $400 \mathrm{kVa}$ 11,5 Kv/400 V. Palembang: Politeknik Negeri Sriwijaya.

[13] Ropikoh, S. U. (2019). Sintesis Nanofiber Kitosan/Polyvinil Alcohol Dengan Metode Electrospinning: Kajian Viskositas Larutan. Departemen Fisika Fakultas Matematika dan Ilmu Pengetahuan Alam Institut Pertanian Bogor.

[14] Shi, X., Zhou, W., Ma, D., Ma, Q., Bridges, D., Ma, Y., \& Hu, A. (2015). Electrospinning of Nanofibers and Their Applications for Energy Devices. Journal of Nanomaterials.

[15] Sun, Y., Cheng, S., Lu, W., Wang, Y., Zhang, P., \& Yao, Q. (2019). Electrospun Fibers and Their Application in Drug Controlled Release, Biological Dressings, Tissue Repair, and Enzyme Immobilization. Royal Society of Chemistry.

[16] Teo, W. E. (2017). Electrospinning for Nanofiber Production Across Materials Classes. Electrospin Tech.

[17] Widodo, M. (2004). Aplikasi Nanoteknologi di Bidang Tekstil. Kumpulan Makalah Seminar Mahasiswa

[18]Zuliyanto, A. (2017). Desain Sistem Teknologi Tesla Coil Untuk Beban Lampu. Fakultas Teknik ElektroUniversitas Muhammadiyah Surakarta. 